\title{
Feeding overlap in two sympatric species of Rhinella (Anura: Bufonidae) of the Atlantic Rain Forest
}

\author{
Leandro T. Sabagh \& Ana M. P. T. Carvalho-e-Silva \\ Laboratório de Biossistemática de Anfíbios, Departamento de Zoologia, Universidade Federal do Estado do Rio de Janeiro. \\ Avenida Pasteur 458, 20290-240 Rio de Janeiro, Rio de Janeiro, Brasil. E-mail: leandro_sabagh@yahoo.com.br
}

\begin{abstract}
A clear understanding of the relationships between overlapping, similarity, and competition is necessary to understand many of the questions about the structure and operation of a community. Rhinella icterica (Spix, 1824) and Rhinella crucifer (Wied Neuwied, 1821) are sympatric species of toads occurring in the National Park of Serra dos Órgãos in southeastern Brazil. The aim of the present study was to assess the dietary overlap of these two species. Ninety-four stomachs were analyzed, and 2245 prey items were found. Common prey were Hymenoptera, Coleoptera, Diptera, Lepidoptera larvae, Blattaria, Orthoptera, Hemiptera, Opiliones, and Aranaea. Ants were the most important prey in both diets, followed by beetles and cockroaches. The niche breadth of $R$. icterica was 1.76 and of $R$. crucifer was 1.28 . The dietary overlap between the species was $98.62 \%$. A positive correlation was observed between jaw width and prey size consumed by $R$. icterica.

KEY WORDS. Amphibia; diet; Rhinella crucifer; Rhinella icterica.
\end{abstract}

RESUMO. Sobreposição alimentar em duas espécies simpátricas de Rhinella (Anura: Bufonidae) da Mata Atlântica. Um claro entendimento das relações entre sobreposição, similaridade e competição é necessário para entender muitas questões sobre a estrutura e o funcionamento de uma comunidade. Rhinella icterica (Spix, 1824) e Rhinella crucifer (Wied Neuwied, 1821) são espécies simpátricas que ocorrem no Parque Nacional da Serra dos Órgãos, região sudeste do Brasil. O objetivo do presente estudo foi verificar a sobreposição alimentar dessas duas espécies. Foram analisados 94 estômagos e encontradas 2245 presas. Os grupos comuns foram: Hymenoptera, Coleoptera, Diptera, larva de Lepidoptera, Blattaria, Orthoptera, Hemiptera, Opiliones e Aranaea. Formigas foram as presas mais importantes na dieta, seguidas por besouros e baratas. A amplitude de nicho de $R$. icterica foi de 1,76 e a de $R$. cruicifer 1,28 . A sobreposição de nicho alimentar entre as espécies foi de $98,62 \%$. Houve relação positiva entre a largura da mandíbula e a dimensão das presas consumidas em $R$. icterica.

PALAVRAS CHAVE. Amphibia; dieta; Rhinella crucifer; Rhinella icterica.

Resource partition in a community is essential for the understanding of species interactions. Species may be compared on the basis of morphology, microhabitat use, foraging time, and resources consumed (LAwor 1980). Diets are a fundamental aspect of each niche, and it seems reasonable to assume that the structure of a community is based mostly on the way that food is shared among coexisting species (ANDREW \& CHRISTENSEN 2001).

Many studies have been conducted on sympatric amphibians, on their feeding and dietary overlap (ToFt 1980, LimA \& Magnusson 1998, Van Sluys \& Rocha 1998, Duré \& Kehr 2001, 2004, IsACCh \& BARg 2002, Menin et al. 2005), microhabitat use (Van Sluys \& Rocha 1998, Duré \& Kehr 2004, Menin et al. 2005), and foraging time (Lima \& Magnusson 1998, Menin et al. 2005).

The Bufonidae is one of the most widely distributed anuran families in the world. According to an extensive systematic revision (Frost et al. 2006), many species of Bufo Laurenti, 1768 were allocated to the revalidated Chaunus Wagler, 1828. However, another study (Chaparro et al. 2007) recommended the generic name Rhinella Fitzinger, 1826, because Rhinella was found to be nested within Chaunus. Rhinella icterica (Spix, 1824) and Rhinella crucifer (Wied Neuwied, 1821) are sympatric species and share resources as well as call sites and reproduction habitats in the Serra dos Órgãos National Park. Rhinella icterica (marinus group) is distributed through southeastern Brazil, south to eastern Paraguay and the province of Misiones in Argentina. Rhinella crucifer (crucifer group) occurs from Misiones and the northeastern province of Corrientes in Argentina north to eastern Paraguay and southeastern, eastern, and northeastern Brazil (Frost 2007, Marques et al. 2006). Both species have similar reproductive habits and vocalizations (IzECKSOHN \& Carvalho-e-Silva 2001). Haddad et al. (1990) reported natural hybridization between both species, although the progeny are inviable, generating no descendents.

The aim of the present study was to assess the existence of feeding overlap between these two species of toads in the National Park of Serra dos Órgãos, state of Rio de Janeiro, Brazil. 


\section{MATERIAL AND METHODS}

The National Park of Serra dos Órgãos (PARNA/SO) is located in southeastern Brazil, state of Rio de Janeiro, at $22^{\circ} 26^{\prime} \mathrm{S}$, $42^{\circ} 59^{\prime} \mathrm{W}$ (altitude about $995 \mathrm{~m}$ ). It is located in the biogeographical province of Serra do Mar and in the Tropical Atlantic morphoclimatic domain. It is situated in a climactic strip that varies from hot to super-hot and super-humid, with a general tropical super-humid climate (80 to $90 \%$ relative humidity), an annual mean temperature of 13 to $23^{\circ} \mathrm{C}$, and a mean annual precipitation of 1,700 to $3,600 \mathrm{~mm}$ (IвAMA 2007). The vegetation is a dense ombrophilous forest, which harbors a diverse anuran fauna.

Sampling was carried out from December 2004 to February 2007 , non-periodically, totalling roughly 270 -field hours. Anurans were collected manually. The snout-urostyle length (SUL) and jaw width (JW) were measured by means of a caliper to the nearest $0.1 \mathrm{~mm}$. All measurements are presented in the following sequence: mean followed by maximum-minimum and standard deviation. A stomach-flushing method adapted from LECLERC \& Courtors (1993) was used to collect food items. Anurans that had their stomachs flushed were marked with a color code to avoid pseudoreplication, and were returned to the area where they were found. The obtained items were measured as length and width (with a caliper to the nearest $0.1 \mathrm{~mm}$ ) and their volume was estimated by the ellipsoid formula $\mathrm{V}=4 / 3 . \pi . \mathrm{L} / 2$. (W/2) 2 (Colli \& Zamboni 1999), where $\mathrm{L}=$ item length and $\mathrm{W}=$ item width.

Snout-urostyle length and jaw width of both species were compared using Student's t test (Zar 1999), to assess morphological differences. An index of relative importance (IRI), proposed by PIANKA et al. (1971) was used, IRI = \%O.(\%N + \%V) where $\% \mathrm{O}=$ relative occurrence; $\% \mathrm{~N}$ = relative abundance and $\% \mathrm{~V}=$ relative volume. The trophic niche breadth was calculated using the formula proposed by Levins (1968) $\mathrm{B}=1 / \Sigma \mathrm{p}_{\mathrm{j}}^{2}$, where $\mathrm{B}=$ niche breadth and $\mathrm{pj}=$ proportion of item $\mathrm{j}$ in the diet. To restrict the breadth to a known interval from 0 to 1 , the formula $\mathrm{B}_{\mathrm{A}}=\mathrm{B}-1 / \mathrm{n}-1$ was used, where $\mathrm{B}_{\mathrm{A}}=$ standardized Levins index and $\mathrm{n}=$ number of possible resources. An overlapping niche was used only when the species were collected simultaneously, to avoid influencing results via resource availability. The overlapping formula $\mathrm{C}_{\mathrm{H}}=2 \Sigma \mathrm{p}_{\mathrm{ij}} \mathrm{p}_{\mathrm{ik}} / \Sigma \mathrm{p}_{\mathrm{ij}}{ }^{2}+\Sigma \mathrm{p}_{\mathrm{ik}}{ }^{2}$, was used, where $\mathrm{CH}=$ Morisita-Horn index (Horn 1966) of niche overlap, $\mathrm{p}_{\mathrm{ij}}=$ corresponding proportion of resource $i$ in the total resource used by species $j, p_{i k}=$ corresponding proportion of resource $i$ in the total resource used by species $\mathrm{k}$. The index ranges from 0 to 1 , where 0 indicates no overlapping and 1 indicates total overlapping. A simple linear regression was plotted between prey size (mean, highest and lowest volume per stomach) and jaw width, total volume per stomach versus SUL, and total number of prey items per stomach versus SUL.

\section{RESULTS}

Ninety-four stomachs were analyzed; 64 belonged to $R$. icterica (51 males, 13 females) and 30 to $R$. crucifer ( 28 males, 2 females). Four of the stomachs were empty (4.26\%). The SUL
(R. icterica 91.43; 62.8-155.0; 20.01) (R. crucifer 69.70; 58.1-90.2; 7.10 ) and JW (R. icterica 34.42; 22.0-58.7; 7.80) (R. crucifer 23.77; $18.6-30.5$; 2.67$)$ showed significant differences between the species $\left(\mathrm{p}<0.01 ; \mathrm{T}_{\text {SUL }}=5.768\right.$ with 92 degrees of freedom; $\mathrm{T}_{\mathrm{JW}}=7.297$ with 90 degrees of freedom).

We found 2,245 food items, which are listed in table I. All items that could be identified to different taxonomic levels are listed in table II. Traces of molted skin were recorded in three stomachs (two R.icterica and one R. crucifer) but were not quantified. Plant remains such as leaves, small twigs and seeds, as well as dirt and small stones were also observed in 44 (46.81\%) stomachs (36 R. icterica and eight $R$. crucifer). Plastic from candy and cigarette packages, small styrofoam spheres, and strands of hair were found in some stomachs.

Rhinella icterica had 27 food items, whereas R. crucifer had only 16. Preys common to both species were: Hymenoptera, Coleoptera (adults and larvae), Diptera (adults and larvae), Lepidoptera larvae, Blattaria, Orthoptera, Hemiptera, Opiliones, and Araneae. Items consumed only by $R$. icterica were: adult Lepidoptera, adult Tricoptera, Neuroptera larvae, winged Isoptera, Dermaptera, Plecoptera and Odonata naiads, Ephemeroptera subimagos, Isopoda, Diplopoda, Chilopoda, Oligochaeta, and Gastropoda. Items consumed only by R. crucifer were: Colembolla, Hirudinea, and Nematomorpha.

Ants were the dominant prey, with the highest absolute values in all analyzed stomachs. Excluding empty stomachs, there was $100.0 \%$ ant occurrence in $R$. icterica and $90.0 \%$ in $R$. crucifer. Beetles were important in both diets, especially in $R$. icterica, where their relative volume was twice that of ants. However, according to the IRI (Tab. I), ants were the most important items in the diet of both species, particularly $R$. crucifer. Beetles were the second most important item in both diets, with occurrence and frequency inferior only to ants. In $R$. icterica, a larger relative volume of beetles was found (Tab. I).

Rhinella icterica niche breadth was $B=1.76\left(B_{A}=0.03\right)$, and that of $R$. crucifer was $B=1.28\left(B_{A}=0.02\right)$, and the feeding niche overlap between species was $98.62 \%$. There was a significant positive correlation in all three $R$. icterica regressions $(\mathrm{p}<0.05)(\mathrm{JW} \mathrm{x}$ Higher vol. $\mathrm{r}^{2}=0.1741 ; \mathrm{p}=0.0091 ; \mathrm{JW}$ x Lower vol. $\mathrm{r}^{2}=0.1006$; $\mathrm{p}=0.0135 ; \mathrm{JW} \times$ Mean vol. $\left.\mathrm{r}^{2}=0.1428 ; \mathrm{p}=0.0029\right)$. No regressions between JW of $R$. crucifer and prey size were significant $(\mathrm{p}>0.05)$ (JW $x$ Higher vol. $\mathrm{r}^{2}=0.1094 \mathrm{p}=0.0798$; JW $\mathrm{x}$ Lower vol. $\mathrm{r}^{2}=0.0096 \mathrm{p}=0.6133$; JW x Mean vol. $\mathrm{r}^{2}=0.0853 \mathrm{p}=0.1241$ ).

The regression between total volume per stomach and SUL for $R$. icterica was significant $\left(\mathrm{r}^{2}=0.1225 \mathrm{p}=0.01\right)$. For $R$. crucifer this regression was not significant $\left(\mathrm{r}^{2}=0.0064 \mathrm{p}=0.67\right)$. No regressions between total number of prey items per stomach and SUL were significant $(\mathrm{p}>0.05)$.

\section{DISCUSSION}

Although these toads differ in size, their diets were quite similar. Rhinella icterica $(\mathrm{n}=64)$ showed a wider feeding spectrum than $R$. crucifer $(\mathrm{n}=30)$, perhaps because more individu- 
Table I. Prey categories with their respective absolute values and relative abundance $(\mathrm{N}$ and $\% \mathrm{~N})$, occurrence $(\mathrm{O}$ and $\% \mathrm{O})$, volume $(\mathrm{V}$ and $\% \mathrm{~V}$ ) and index of relative importance (IRI).

\begin{tabular}{|c|c|c|c|c|c|c|c|c|c|c|c|c|c|c|}
\hline & \multicolumn{7}{|c|}{ Rhinella icterica } & \multicolumn{7}{|c|}{ Rhinella crucifer } \\
\hline & $\mathrm{N}$ & $\% \mathrm{~N}$ & $\mathrm{O}$ & $\% \mathrm{O}$ & $V\left(\mathrm{~mm}^{3}\right)$ & $\% \mathrm{~V}$ & IRI & $\mathrm{N}$ & $\% \mathrm{~N}$ & $\mathrm{O}$ & $\% \mathrm{O}$ & $\mathrm{V}\left(\mathrm{mm}^{3}\right)$ & $\% \mathrm{~V}$ & IRI \\
\hline \multicolumn{15}{|l|}{ Arthropoda } \\
\hline \multicolumn{15}{|l|}{ Hexapoda } \\
\hline Formicidae & 1198 & 74.55 & 61 & 100.00 & $25,775.98$ & 22.92 & 97.47 & 559 & 88.03 & 27 & 90.00 & $7,574.75$ & 51.81 & 125.86 \\
\hline $\begin{array}{l}\text { Hymenoptera non- } \\
\text { Formicidae }\end{array}$ & 3 & 0.19 & 3 & 4.92 & 35.96 & 0.03 & 0.01 & 2 & 0.31 & 2 & 6.67 & 118.36 & 0.81 & 0.07 \\
\hline Coleoptera (adult) & 144 & 8.96 & 49 & 80.33 & $50,876.74$ & 45.24 & 43.54 & 30 & 4.72 & 15 & 50.00 & $3,565.51$ & 24.39 & 14.56 \\
\hline Coleoptera (larvae) & 7 & 0.44 & 7 & 11.48 & 499.99 & 0.44 & 0.10 & 3 & 0.47 & 3 & 10.00 & 99.95 & 0.68 & 0.12 \\
\hline Diptera (adult) & 11 & 0.68 & 8 & 13.11 & 77.67 & 0.07 & 0.10 & 5 & 0.79 & 3 & 10.00 & 9.61 & 0.07 & 0.09 \\
\hline Diptera (larvae + pupa) & 14 & 0.87 & 7 & 11.48 & 86.56 & 0.08 & 0.11 & 2 & 0.31 & 2 & 6.67 & 8.40 & 0.54 & 0.06 \\
\hline Lepidoptera (adult) & 1 & 0.06 & 1 & 1.64 & 74.86 & 0.07 & 0.00 & - & - & - & - & - & - & - \\
\hline Lepidoptera (larvae) & 62 & 3.86 & 15 & 24.59 & $3,494.42$ & 3.11 & 1.71 & 4 & 0.63 & 4 & 13.33 & 279.24 & 1.91 & 0.34 \\
\hline Tricoptera (adult) & 2 & 0.12 & 2 & 3.28 & 28.49 & 0.03 & 0.00 & - & - & - & - & - & - & - \\
\hline Neuroptera (larvae) & 1 & 0.06 & 1 & 1.64 & 33.46 & 0.03 & 0.00 & - & - & - & - & - & - & - \\
\hline Blattaria & 45 & 2.80 & 27 & 44.26 & $18,851.59$ & 16.76 & 8.67 & 8 & 1.26 & 8 & 26.67 & 1948.00 & 13.33 & 3.89 \\
\hline Blattaria (oothecae) & 1 & 0.06 & 1 & 1.64 & 28.18 & 0.03 & 0.00 & - & - & - & - & - & - & - \\
\hline Isoptera & 2 & 0.12 & 1 & 1.64 & 21.18 & 0.02 & 0.00 & - & - & - & - & - & - & - \\
\hline Orthoptera & 19 & 1.18 & 14 & 22.95 & $1,186.88$ & 1.06 & 0.51 & 2 & 0.31 & 2 & 6.67 & 210.27 & 1.44 & 0.12 \\
\hline Dermaptera & 1 & 0.06 & 1 & 1.64 & 46.47 & 0.04 & 0.00 & - & - & - & - & - & - & - \\
\hline Hemiptera & 14 & 0.87 & 11 & 18.03 & 461.24 & 0.41 & 0.23 & 5 & 0.79 & 4 & 13.33 & 263.92 & 1.81 & 0.35 \\
\hline Plecoptera (naiad) & 1 & 0.06 & 1 & 1.64 & 63.15 & 0.06 & 0.00 & - & - & - & - & - & - & - \\
\hline Odonata (naiad) & 1 & 0.06 & 1 & 1.64 & 367.46 & 0.33 & 0.01 & - & - & - & - & - & - & - \\
\hline Ephemeroptera & 1 & 0.06 & 1 & 1.64 & 6.67 & 0.01 & 0.00 & - & - & - & - & - & - & - \\
\hline Collembola & - & - & - & - & - & - & - & 1 & 0.16 & 1 & 3.33 & 0.54 & 0.00 & 0.01 \\
\hline \multicolumn{15}{|l|}{ Arachnida } \\
\hline Opiliones & 20 & 1.24 & 12 & 19.67 & $3,439.63$ & 3.06 & 0.85 & 3 & 0.47 & 3 & 10.00 & 367.84 & 2.52 & 0.30 \\
\hline Araneae & 25 & 1.56 & 17 & 27.87 & $2,033.54$ & 1.81 & 0.94 & 4 & 0.63 & 4 & 13.33 & 85.48 & 0.58 & 0.16 \\
\hline \multicolumn{15}{|l|}{ Crustacea } \\
\hline Isopoda & 4 & 0.25 & 4 & 6.56 & 328.50 & 0.29 & 0.04 & - & - & - & - & - & - & - \\
\hline \multicolumn{15}{|l|}{ Myriapoda } \\
\hline Diplopoda & 2 & 0.12 & 2 & 3.28 & $1,064.61$ & 0.95 & 0.04 & - & - & - & - & - & - & - \\
\hline Chilopoda & 3 & 0.19 & 3 & 4.92 & $1,191.54$ & 1.06 & 0.06 & - & - & - & - & - & - & - \\
\hline \multicolumn{15}{|l|}{ Annelida } \\
\hline Oligochaeta & 6 & 0.37 & 6 & 9.84 & $1,165.70$ & 1.04 & 0.14 & - & - & - & - & - & - & - \\
\hline Hirudinea & - & - & - & - & - & - & - & 1 & 0.16 & 1 & 3.33 & 1.88 & 0.81 & 0.07 \\
\hline \multicolumn{15}{|l|}{ Mollusca } \\
\hline Gastropoda & 15 & 0.93 & 2 & 3.28 & 958.14 & 0.85 & 0.06 & - & - & - & - & - & - & - \\
\hline \multicolumn{15}{|l|}{ Nematomorpha } \\
\hline Gordioida & - & - & - & - & - & - & - & 4 & 0.63 & 2 & 6.67 & 6.87 & 0.05 & 0.05 \\
\hline Skin & 2 & 0.12 & 2 & 3.28 & - & - & - & 1 & 0.16 & 1 & 3.33 & - & - & - \\
\hline Unidentified remains & 4 & 0.25 & 4 & 6.56 & 255.70 & 0.23 & 0.03 & 2 & 0.31 & 2 & 6.67 & 78.51 & 0.54 & 0.06 \\
\hline
\end{tabular}


Table II. Items found in the stomachs of $R$. icterica and $R$. crucifer. (Im) Immature, $\left(^{*}\right)$ aquatic.

\begin{tabular}{|c|c|c|}
\hline & R. icterica & R. crucifer \\
\hline \multicolumn{3}{|l|}{ Arthropoda } \\
\hline \multicolumn{3}{|l|}{ Uniramia } \\
\hline \multicolumn{3}{|l|}{ Myriapoda } \\
\hline \multicolumn{3}{|l|}{ Diplopoda } \\
\hline Polydesmida & $x$ & - \\
\hline Chilopoda & $x$ & - \\
\hline \multicolumn{3}{|l|}{ Hexapoda } \\
\hline \multicolumn{3}{|l|}{ Entognatha } \\
\hline Collembola & - & $x$ \\
\hline \multicolumn{3}{|l|}{ Insecta } \\
\hline \multicolumn{3}{|l|}{ Hymenoptera } \\
\hline \multicolumn{3}{|l|}{ Formicidae } \\
\hline Atta & - & $x$ \\
\hline Acromyrmex & $x$ & $x$ \\
\hline Brachymyrmex & $x$ & - \\
\hline Odontomachus & $x$ & $x$ \\
\hline Camponotus & $x$ & $x$ \\
\hline Pachycondyla & $x$ & $x$ \\
\hline Pheidole & $x$ & $x$ \\
\hline Pseudomyrmex & $x$ & - \\
\hline Solenopsis & $x$ & $x$ \\
\hline Brachonoida & $x$ & $x$ \\
\hline \multicolumn{3}{|l|}{ Coleoptera } \\
\hline Curculidae & $x$ & $x$ \\
\hline Scarabidae & $x$ & $x$ \\
\hline Cantharidae & $x$ & - \\
\hline Pselaphidae* (Im) & $x$ & - \\
\hline Staphylinidae & $x$ & $x$ \\
\hline Helodidae (Im) & $x$ & - \\
\hline Hidrophilidae* (Im) & - & $x$ \\
\hline \multicolumn{3}{|l|}{ Diptera } \\
\hline \multicolumn{3}{|l|}{ Nematocera } \\
\hline Chaoboridae (Im) & - & $x$ \\
\hline Chironomidae* $^{*}(\mathrm{Im})$ & $x$ & - \\
\hline \multicolumn{3}{|l|}{ Brachycera } \\
\hline Ephydridae & $x$ & - \\
\hline Lepidoptera & $x$ & $x$ \\
\hline \multicolumn{3}{|l|}{ Orthoptera } \\
\hline Gryllidae & $x$ & $x$ \\
\hline \multicolumn{3}{|l|}{ Isoptera } \\
\hline Termitidae & $x$ & - \\
\hline \multicolumn{3}{|l|}{ Blattaria } \\
\hline Blattellidae & $x$ & $x$ \\
\hline \multicolumn{3}{|l|}{ Plecoptera } \\
\hline Perlidae* $^{*}(\mathrm{Im})$ & $x$ & ${ }^{-}$ \\
\hline
\end{tabular}

Table II. Continued.

\begin{tabular}{|c|c|c|}
\hline & R. icterica & R. crucifer \\
\hline \multicolumn{3}{|l|}{ Dermaptera } \\
\hline Forficulidae & $x$ & - \\
\hline \multicolumn{3}{|l|}{ Hemiptera } \\
\hline \multicolumn{3}{|l|}{ Auchenorrhyncha } \\
\hline Cicadellidae & $x$ & $x$ \\
\hline Membracidae & $x$ & $x$ \\
\hline Sternorryncha & $x$ & $x$ \\
\hline \multicolumn{3}{|l|}{ Odonata } \\
\hline Libellulidae* (Im) & $x$ & - \\
\hline Ephemeroptera & & - \\
\hline Battidae* & $x$ & - \\
\hline \multicolumn{3}{|l|}{ Cheliceriformes } \\
\hline \multicolumn{3}{|l|}{ Chelicerata } \\
\hline Araneae & $x$ & $x$ \\
\hline Idiopidae & $x$ & - \\
\hline \multicolumn{3}{|l|}{ Opiliones } \\
\hline Gonyleptidae & $x$ & $x$ \\
\hline \multicolumn{3}{|l|}{ Crustacea } \\
\hline \multicolumn{3}{|l|}{ Malacostraca } \\
\hline \multicolumn{3}{|l|}{ Isopoda } \\
\hline Oniscoidea & $x$ & - \\
\hline \multicolumn{3}{|l|}{ Annelida } \\
\hline Oligochaeta & $x$ & - \\
\hline Hirudinea & $x$ & - \\
\hline \multicolumn{3}{|l|}{ Mollusca } \\
\hline \multicolumn{3}{|l|}{ Gastropoda } \\
\hline \multicolumn{3}{|l|}{ Basommatophora } \\
\hline Physidae & $x$ & - \\
\hline \multicolumn{3}{|l|}{ Nematomorpha } \\
\hline Gordioida & - & $x$ \\
\hline
\end{tabular}

als of the former were sampled. The most important food items were ants and beetles for both species. Data on the diet of $R$. icterica in the higher-altitude section of Itatiaia National Park (PARNA/I) demonstrated a narrower spectrum, of only five orders. This difference probably is due to prey availability (richness) in a dense ombrophilous forest, such as PARNA/SO, being higher than in high-altitude plains (altitude 2,350 m), such as the higher portion of PARNA/I. BRAUN (1978) demonstrated that captive individuals of $R$. icterica feed abundantly, readily accepting insects, worms, and a diet based on mice, showing that this species is not selective.

Many authors classify Bufonidae as ant-specialists (ToFT 1980, Flowers \& Graves 1995, Rosa et al. 2002, Isacch \& BarG 2002), while others prefer to classify them as generalists (SмIтH \& Bragg 1949, Evans \& Lampo 1996, Grant 1996). 
The low value of the standardized niche breadth of both species and the disproportionally proportion of ants in the diet suggest that $R$. icterica and $R$. crucifer are specialists. On the other hand, the wide trophic spectrum, particularly in $R$. icterica, contrasts with this conclusion and supports their classification as generalists. IsACCH \& BARG (2002) believed that bufonids are ant-specialists, due to their small size and lack of teeth. However R. icterica and R. crucifer are not small bufonids, and their thick skin (see Brito-Gitirana \& Azevedo 2005) probably makes them more resistant to ant bites and stings, allowing them to feed on these insects for longer periods. Tofт (1980) argued that ant-specialists feed on slow-moving, chitinous prey, whereas non ant-specialists consume more-agile preys. Both species studied herein consumed agile prey such as cockroaches, crickets, and spiders. Further, ants, along with termites, compose approximately $70 \%$ of the animal biomass in tropical humid forests (HÖLLDOBLER \& WILSON 1990), and Formicidae show eusocial behavior, with the habit of walking on trails, usually in groups. These habits may explain the high numbers of ants found in toad stomachs, and their higher importance in the feeding habits of the anuran species studied. The relatively few records of termites may be due to their cryptic habits, since they travel in tunnels to protect themselves; both individuals found were winged males, which may have fallen to the ground.

Because the trophic-niche breadth values were low and the spectrum was high, we believe that it cannot be said that both species of Rhinella are ant-specialists, without knowing all the resources available and applying electivity tests, since in most cases amphibian diets reflect prey availability in the environment (Duellman \& Trueb 1994). Isacch \& Barg (2002) found electivity by ants in Rhinella arenarum (Hensel, 1867) and Rhinella dorbignyi (Duméril and Bibron, 1841) in the Pampas (lowland plains): DAMASCENO (2005), studying Rhinella granulosa (Spix, 1824) in the Caatinga, found positive electivity for ants, and inferred that this preference could be associated with toxin synthesis, a relationship accepted for dendrobatids (CALDWELl 1996). SANTANA \& JuNCÁ (2007), also studying Rhinella granulosa (Spix, 1824) in the Chapada Diamantina, found positive electivity for isopterans and low electivity for ants.

Beetles were very important in the diets of both species, which corroborates many previous studies (LajMANOvich 1994, Evans \& Lampo 1996, Grant 1996, Rosa et al. 2002), and contrasts with the observations of IsACCH \& BARG (2002), who found a negative electivity for this kind of prey, and of SANTANA \& JUNCÁ (2007), who found low frequencies for Coleoptera. Although other authors (Lajmanovich 1994, Evans \& Lampo 1996, Teixeira et al. 1999, Isacch \& Barg 2002, Rosa et al. 2002, SANTANA \& Juncá 2007) did not observe cockroaches in the diets of species of Rhinella, their abundance, occurrence, and volume were still important in the present study. The presence of aquatic prey, such as Plecoptera and Odonata naiads, an Ephemeroptera sub-imago, mosquito larvae, and some Coleoptera families (Pselaphidae and Hidrophilidae), suggests that $R$. icterica and $R$. crucifer feed in water bodies.
The phylum Nematomorpha belongs to the group Aschelminthes; the larva is a frequent arthropod parasite and the adult is free-living (RUPPERT \& BARNES 1996). Although these specimens were found intact, it was not possible to identify their stage of development. In the stomach in which they were found, there were also potential hosts. Because the food items were immediately immersed in $70 \%$ alcohol, the possibility that these aschelminths were alive inside the anuran could not be verified.

Most anurans are predators, and probably the plant remains were ingested accidentally, as many workers have suggested (Evans \& LAmpo 1996, Teixeira et al. 1999, VAN Sluys et al. 2001). However, LajMANOvich (1994), studying Rhinella schneideri (Werner, 1894), observed that plant remains collected at the end of the digestive tube, except seeds, showed some signs of digestion. Despite of that observation, this same author believed that the plant remains were accidentally ingested and may have come from leafcutter ants. As related in table II, leafcutter ants (Acromyrmex and Atta) were also found in the stomachs of $R$. icterica and R. crucifer. ANDERSON et al. (1999) proposed that ingestion of plant tissue, even without any nutritional value, is not incidental, and help the anuran to avoid parasites and dehydration.

Grant (1996) observed pieces of plastic in the stomach of Rhinella marinus (Linnaeus, 1758); these must have been ingested accidentally, as the plastic pieces and styrofoam were in $R$. icterica. The strong human impact on the area unfortunately exposes the animals to these hazards.

The presence of their own skin in the stomachs of both species corroborates the data collected by Evans \& LAMPO (1996), TeIXeIra et al. (1999), and L.T. SABAGH, who worked with different species of Rhinella. WELDON et al. (1993) affirmed that this is a common habit in amphibians, which re-use part of their skin during molting. Bustard \& MADERson (1965) believed that this is a mechanism used for reclaiming their epidermal proteins.

Although significant, linear regression do not support ( $\mathrm{r}^{2}$ little representative) ontogenetic change in the diet like suggested by some authors for others anuran species.

We conclude that electivity tests are necessary to assess whether the studied species are specialists or generalists and that there is a strong trophic-niche overlap between both species. However, the occurrence of overlap, even to a high degree, does not necessarily mean that competition is present, if the resource is not limited.

\section{ACKNOWLEDGMENTS}

To the post-graduate program in Aquatic Biology (UNIRIO) for a scholarship. To Direction of the PARNA/SO for local support and for making many facilities available. To Elidiomar R. da Silva for help in identifying arthropods; Tiago Viana for identifying gastropods; and Ricardo Cardoso, Davor Vrcibradic, and two anonymous referees for helpful suggestions. 


\section{LITERATURE CITED}

Anderson, A.M.; D.A. Haukos \& J. Anderson. 1999. Diet composition of three anurans from the Playa Wetlands of Northweast Texas. Copeia 2: 515-520.

Andrew, S. \& B. Christensen. 2001. Optimal diet theory: when does it work, and when and why does it fail? Animal Behavior 61: 379-390.

Braun, C.A.S. 1978. Levantamento dos anfíbios venenosos do Estado do Rio Grande do Sul, Brasil. Parte I - Família Bufonidae. Iheringia, Série Zoologia, 52: 73-83.

Brito-Gitirana, L \& R.A. Azevedo. 2005. Morphology of Bufo ictericus integument (Amphibia, Bufonidae). Micron 36: 532538.

Bustard, H.R. \& P.F.A. Manderson. 1965. The eating of shed epidermal material in squamate reptiles. Herpetologica 21: 306-308.

Caldwell, J.P. 1996. The evolution of myrmecophagy and its correlates in poison frog (Family Dendrobatidae). Journal of Zoology 240: 75-101.

Chaparro, J.C.; J.B. Pramuk \& A.G. Gluesenkamp. 2007. A new species of arboreal Rhinella (Anura: Bufonidae) from cloud forest of Southeastern Peru. Herpetologica 63(2): 203-212.

Colli, G.R. \& D.S. Zamboni. 1999. Ecology of the worm-lizard Amphisbaena alba in the cerrado of central Brazil. Copeia 3: 733-742.

DAMAsceno, R. 2005. Uso de recursos alimentares e eletividades na dieta de uma assembléia de anuros terrícolas das dunas do médio Rio São Francisco, Bahia. Biota Neotropica 5(1). Available on line at: http://www.biotaneotropica.org.br/ v5n2/pt/abstract?article+BN02405022005

Duellman, W. \& L. Trueb. 1994. Biology of amphibians. New York, McGraw-Hill Book, 670p.

Duré, M. I. \& A. Kenr 2001. Differential exploitation of trophic resources by two pseudid frog from Corrientes, Argentina. Journal of Herpetology 35 (2): 340-343.

Duré, M.I. \& A. KeHr. 2004. Influence of microhabitat on the trophic ecology of two Leptodactylids from Northeastern Argentina. Herpetologica 60 (3): 295-303.

Evans, M. \& M. Lampo. 1996. Diet of Bufo marinus in Venezuela. Journal of Herpetology 30 (1): 73-76.

Flowers, M.A. \& B.M. Graves. 1995. Prey selectivity and sizespecific diet changes in Bufo cognatus and Bufo woodhousii during early postmetamorphic ontogeny. Journal of Herpetology 29 (4): 608-612.

Frost, D.R. 2007. Amphibian Species of the World: an Online Reference. Version 5.0. Available on line at: http:// research.amnh.org/herpetology/amphibia/index.php [Accessed in 21/II/2007]

Frost, D.R.; T. Grant; J. Faivovich; R.H. Bain; A. HaAs; C.F.B. Haddad; R.O. De Sá; A. Channing; M. Wilkinson; S.C. Donnellan; C.J. Raxworthy; J.A. Campbell; B.L. Blotto; P. Moler; R.C. Drewes; R.A. Nussbaum; J.D. Lynch; D.M. Green \& W.C. Wheeler. 2006.
The amphibian tree of life. Bulletin of the American Museum of Natural History 297 (1): 1-291.

Grant, G.S. 1996. Prey of the introduced Bufo marinus on American Samoa. Herpetelogical Review 27 (2): 67-69.

Haddad, C.F.B.; A.J. CaRdoso \& L.M. CaSTANHO. 1990. Hibridação natural entre Bufo ictericus e Bufo crucifer (Amphibia: Anura). Revista Brasileira de Biologia 50 (3): 739-744.

Hölldobler, B. \& E.O. Wilson. 1990. The Ants. Cambridge, Belknap Press of Harvard University Press, 732p.

Horn, H.S. 1966. Measurement of.overlap in comparative ecological studies. The American Naturalist 100: 419-424.

Iвама. 2007. Parque Nacional Serra dos Órgãos. Available on line at: http://www.ibama.gov.br/parnaso [Accessed in 11/ III/2007]

IsACCH, J.P. \& M. BARG. 2002. Are bufonid toads specialized antfeeders? A case test from the Argentinian flooding pampa. Journal of Natural History 36: 2005-2012.

Izecsohn, E \& S.P. Carvalho-e-Silva. 2001. Anfíbios do Município do Rio de Janeiro. Rio de Janeiro, Editora UFRJ, 147p.

LajManovich, R.C. 1994. Habitos alimentarios de Bufo paracnemis (Amphibia, bufonidae) en el Parami medio, Argentina. Revista de Hydrobiologia Tropical 27 (2): 107-112.

LAWOR, L.R. 1980. Overlap, similarity, and competiton coefficients. Ecology 61 (2): 245-251.

Leclerc, J. \& D. Courtois. 1993. A simple stomach flushing method for ranid frogs. Herpetological Review 24: 142-143.

Levins, R. 1968. Evolution in changing environments: some theoretical explorations. Princeton, Princeton University Press, 132p.

Lima, A.P. \& W.E. Magnusson. 1998. Partitioning seasonal time: interactions among size, foraging activity and diet in leatlitter frogs. Oecologia 116: 259-266.

Marques, R.A.; B.B. Annunziata \& A.M.P.T. Carvalho-e-Silva. 2006. Geographic distribution. Bufo crucifer. Herpetological Review 37 (1): 98-98.

Menin, M.; D.C. Rossa-Feres \& A. A. Giaretta. 2005. Resource use and coexistence of two syntopic hylid frogs (Anura, Hylidae). Revista Brasileira de Zoologia 22 (1): 61-72.

Pianka, L.; M.S. Oliphant \& Z.L. Iverson. 1971. Food habits of albacore bluefin, tuna and bonito in California waters. California Department of Fish and Game Bulletin 152: 1-350.

Rosa, I.; A. Canavero; R. Maneyro; D.E. Naya \& A. Camargo. 2002. Diet of four sympatric anuran species in a temperate environment. Boletin de la Sociedad Zoologica del Uruguay 13: 12-20.

Rupert, E.E. \& R.D. BARnes. 1996. Zoologia de Invertebrados. São Paulo, Editora Roca, VI+1029p.

Santana, A.S. \& F.A. Juncá. 2007. Diet of Phusalaemus cf. cicada (Leptodactylidae) and Bufo granulosus (Bufonidae) in a semideciduous forest. Brazilian Journal of Biology 67 (1): 125131.

Smith, C.C. \& A.N. Bragg. 1949. Observations on the ecology and natural history of anura, VII. Food and feeding habits 
of the common species of toads in Oklahoma. Ecology 30 (3): 333-349.

Teixeira, R.L.; J.A.P. Schineider \& M. Giovanelli. 1999. Diet of the toad Bufo granulosus (Amphibia, Bufonidae) from sandy coastal plain in southeastern Brazil. Boletim do Museu de Biologia Mello Leitão, Nova Série, 10: 29-31.

ToFт, C.A. 1980. Feeding ecology of thirteen syntopic species of anurans in a seasonal tropical environment. Oecologia 45: 131-141.

Van Sluys, M. \& C.F.D. Rocha. 1998. Feeding habits and microhabitat utilization by two syntopic Brazilian Amazonian frogs
(Hyla minuta and Pseudopaludicula sp. (gr. falcipes). Revista Brasileira de Biologia 58 (4): 559-562.

Van Sluys, M.; C.F.D. Rocha \& M.B. Souza. 2001. Diet, reproduction and density of the leptodactylid litter frog Zachaenus parvulus in an Atlantic Rain Forest of southeastern Brazil. Journal of Herpetology 35 (2): 322-325.

Weldon, P.J.; B.J. Demeter, \& R. Rosscoe. 1993. A survey of shed skin-eating (dermatophagy) in amphibians and reptiles. Journal of Herpetology 27: 219-228.

Zar, J.H. 1999. Biostatistical Analysis. New Jersey, PrenticeHall, IV+718p.

Submitted: 31.V.2007; Accepted: 06.VI.2008.

Editorial responsibility: Lena Geise 